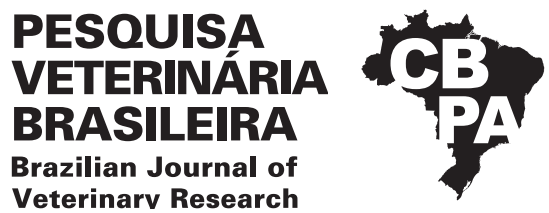

Pesq. Vet. Bras. 40(4):284-288, April 2020 DOI: 10.1590/1678-5150-PVB-6103

Original Article

inarv Research

Small Animal Diseases

ISSN 0100-736X (Print)

(cc) BY-NC

\title{
Progesterone and estrogen receptor expression by canine cutaneous soft tissue sarcomas ${ }^{1}$
}

\author{
Fabricia H. Loures ${ }^{2 *}$ (D) Lissandro G. Conceição ${ }^{3}$, Renee L. Amorim ${ }^{4}$ (D), \\ Juliano Nobrega ${ }^{4}$, Rafael T. Neto ${ }^{5}$, Eduardo P. Costa $^{3}$ and Fabyano Fonseca e Silva ${ }^{6}$
}

\begin{abstract}
Loures F.H., Conceição L.G., Amorim R.L., Nobrega J., Neto R.T., Costa E.P. \& Fonseca e Silva F. 2020 Progesterone and estrogen receptor expression by canine cutaneous soft tissue sarcomas. Pesquisa Veterinária Brasileira 40(4):284-288. Departamento de Veterinária, Universidade Federal de Viçosa, Avenida PH Rolfs s/n, Campus Universitário, Viçosa, MG 36570-000, Brazil. E-mail: fabriciadermatopato.vet@gmail.com

Canine soft tissue sarcomas (STS) comprise a heterogeneous group of malignancies that share similar histopathological features, a low to moderate recurrence rate and low metastatic potential. In human medicine, the expression of estrogen receptors (ER) and progesterone receptors (PR) in sarcomas has been studied to search for prognostic factors and new treatment targets. Similar studies have yet to be conducted in veterinary medicine. The objective of this study was therefore to investigate by immunohistochemistry (IHC) the ER and PR expression in a series of 80 cutaneous and subcutaneous sarcomas in dogs with histopathological features of peripheral nerve sheath tumor (PNST) and perivascular wall tumor (PWT). All cases were positive for PR and negative for ER. Tumors of high malignancy grade (grade III) exhibited higher PR expression than low-grade tumors (grade I). Tumors with mitotic activity greater than 9 mitotic figures/10 high power fields also exhibited higher PR expression. In addition, there was a positive correlation between cell proliferation (Ki67) and PR expression. Therefore, it is possible that progesterone plays a greater role than estrogen in the pathogenesis of these tumors. Future studies should explore the potential for selective progesterone receptor modulators as therapeutic agents in canine STS, as well as evaluating PR expression as a predictor of prognosis.
\end{abstract}

INDEX TERMS: Progesterone, estrogen, receptor expression, canine, cutaneous tissue, soft tissue sarcomas, dogs.

RESUMO.- [Expressão de receptores para progesterona e estrógeno em sarcomas de tecidos moles cutâneos em cães.] Sarcomas de tecidos moles (STM) caninos compreendem um grupo heterogêneo de neoplasias malignas, que apresentam alterações histopatológicas similares, baixa a moderada taxa de recorrência e baixo potencial metastático. Em medicina humana, a expressão de receptor para estrógeno (RE) e receptor para progesterona (RP) nos sarcomas tem sido estudada, visando a busca por fatores prognósticos e novos alvos para tratamentos. Na medicina veterinária, ainda não

\footnotetext{
${ }^{1}$ Received on October 18, 2019.

Accepted for publication on October 29, 2019.

${ }^{2}$ Graduate Program in Veterinary Medicine, Departamento de Veterinária, Universidade Federal de Viçosa (UFV), Avenida PH Rolfs s/n, Campus Universitário, Viçosa, MG 36570-000, Brazil. *Corresponding author: fabriciadermatopato.vet@gmail.com

${ }^{3}$ Departamento de Veterinária, Universidade Federal de Viçosa (UFV), Avenida PH Rolfs s/n, Campus Universitário, Viçosa, MG 36570-000, Brazil.
}

foram realizados estudos similares. 0 objetivo deste trabalho foi investigar por imuno-histoquímica a expressão de RE e RP em uma série de 80 sarcomas cutâneos e subcutâneos de cães, com características histopatológicas de tumor de bainha de nervo periférico e tumor de parede perivascular. Todos os casos foram positivos para RP e negativos para RE. Tumores de alto grau de malignidade (grau III) exibiram maior expressão deste receptor que os tumores de baixo grau (grau I). Tumores com atividade mitótica maior que 9 figuras mitóticas $/ 10$ campos de grande aumento também exibiram

\footnotetext{
${ }^{4}$ Faculdade de Medicina Veterinária e Zootecnia (FMVZ), Universidade Estadual Paulista "Júlio de Mesquita Filho" (Unesp), Rua Prof. Dr. Valter Maurício Corrêa s/n, Botucatu, SP 18618-681, Brazil.

${ }^{5}$ VetMol Consultoria e Diagnóstico em Patologia Molecular Veterinária e Pesquisa, Rua Abílio Dorini 854, Jardim Paraíso II, Botucatu, SP 18610-060, Brazil.

${ }^{6}$ Departamento de Zootecnia, Universidade Federal de Viçosa (UFV), Avenida PH Rolfs s/n, Campus Universitário, Viçosa, MG 36570-000, Brazil.
} 
maior expressão do RP. Em adição, houve correlação positiva entre o índice de proliferação celular (Ki67) e a expressão de RP. Assim, é possível que a progesterona desempenhe maior papel que o estrógeno na patogênese desses tumores. Futuros trabalhos poderão explorar o potencial dos moduladores seletivos de RP como agente terapêutico em STM caninos, bem como avaliar a expressão de RP como preditiva de prognóstico.

TERMOS DE INDEXAÇÃO: Receptores, progesterona, estrógeno, sarcomas, tecidos moles cutâneos, cães, caninos.

\section{INTRODUCTION}

Soft tissue sarcomas (STS) comprise a heterogeneous group of malignant neoplasms, derived from extraskeletal mesenchymal tissues, that share similar histopathological findings and biological behaviour (Ettinger 2003, Dennis et al. 2011). These neoplasms frequently occur in cutaneous and subcutaneous tissue and usually exhibit low metastatic potential and a variable recurrence rate after surgical excision (Dennis et al. 2011, Avallone et al. 2014).

For prognostic purposes and in search of new treatment targets, recent studies in human medicine have evaluated the expression of estrogen receptors (ER) and progesterone receptors (PR) in STS (Ioffe et al. 2009, Valkov et al. 2011, Akashi et al. 2013, Li et al. 2013, Sorbye et al. 2013, Thanopoulou et al. 2014). In dogs, the prognosis related to ER and PR expression was evaluated mainly in mammary neoplasms (Millanta et al. 2005, Millanta et al. 2006). Understanding the influence of steroid hormones on the development of neoplasms may be important for the development of new therapeutic approaches. In addition, investigation of the expression of these receptors in spontaneous animal STS may provide additional information for cancer research in humans (Vail \& Macewen 2000).

The objective of this study was to evaluate by immunohistochemistry (IHC) the expression of ER and PR in canine STS, with morphological compatibility with peripheral nerve sheath tumor (PNST) and perivascular wall tumor (PWT).

\section{MATERIALS AND METHODS}

This study was approved by the Ethics Committee for Animal Use (CEUA/UFV, proccess no. 95/2014).

Inclusion criteria and case selection. Microscopic slides of canine STS from the Pathology Service were reviewed. Cases with morphological and immunohistochemical findings compatible with PNST and/or PWT were included in the study. The cases showed positive immunostaining for neural markers and muscular markers, according to the panel of antibodies presented below. Canine STS with morphological findings suggestive of other sarcomas (e.g. fibrosarcoma, liposarcoma, myxosarcoma, leiomyosarcoma and rhabdomyosarcoma) were not included in the study.

Clinical records information. The clinical information regarding sex, age, breed, location and size of the lesions was obtained from the clinical and pathological records.

Histopathology and immunohistochemistry (IHC). Hematoxilin and eosin (HE) stained slides were reviewed under light microscopy for tumor grading. Histological grade was based on the sum of scores attributed to the mitotic rate, percentage of necrosis and differentiation of the neoplasm as previously described (Dennis et al. 2011).
For IHC analysis, the paraffin blocks were cut into $3 \mu \mathrm{m}$ thick sections and placed on electrically charged plates (Starfrost ${ }^{\circledR}$ ). The antibody dilutions and clones were as follows: Progesterone Receptor Ab-2 Mouse Monoclonal Antibody (Thermo Scientific, Runcorn, UK; hPRa2; 1:50); Monoclonal Mouse Anti-Human Estrogen Receptor (Dako, Glostrup, Denmark; ID5; 1:20); Monoclonal Mouse Anti-Human Ki-67 (Dako, Glostrup, Denmark; MIB-1; 1:50); Antigen CD56 (Biocare Medical, Concord/CA, USA; BC56C04; 1:200); Monoclonal Mouse Anti-Human Smooth Muscle Actin (Dako, Glostrup, Denmark; A4; 1:1000); Monoclonal Mouse Anti-Human Desmin (Dako, Glostrup, Denmark; D33; 1:50); Polyclonal Rabbit Anti-Human Von Willebrand Factor (Dako, Glostrup, Denmark; Polyclonal; 1:1000); Monoclonal Mouse Anti-Human Neuron-Specific Enolase (NSE) (Dako, Glostrup, Denmark; BBS/NC/VI-H14; 1:3000); Glial Fibrillary Acidic Protein Rabbit Polyclonal Antibody (Diagnostic BioSystems, Pleasanton/ CA; Polyclonal; 1:300).

After incubation at $54^{\circ} \mathrm{C}$ for $24 \mathrm{~h}$, tissue sections were deparaffinized in xylene, hydrated in ethanol and washed with deionized water. For antigen retrieval, citrate was used at $\mathrm{pH} 6.0$ in a pressure cooker. The endogenous peroxidase blockage was performed with $3 \%$ hydrogen peroxide for $10 \mathrm{~min}$. After washing, the primary antibody and slides were kept in a moist chamber at $4^{\circ} \mathrm{C}$ for $18 \mathrm{~h}$. After washing with Tris at $\mathrm{pH} 7.4$, a peroxidase-bound secondary antibody polymer system was used according to the manufacturer's recommendations (EnVision, DakoCytomation ${ }^{\circledR}$ ). Visualization was accomplished with 3,3'-diaminobenzidine tetrachloride (DakoCytomation ${ }^{\circledR}$ ) and counterstaining with Harris hematoxylin. Internal positive controls (muscle tissue and endothelial cells) were used to smooth muscle actin, desmin, and Von Willebrand factor. Canine cystic endometrial hyperplasia tissue was used as the positive control for ER and PR. For other antibodies, the positive control consisted of tumors known to be positive for that particular antibody. For all the used antibodies, negative controls were performed by omitting the primary antibodies.

The IHC interpretation was performed under light microscopy. Areas with intense inflammation or necrosis were avoided, since inflammatory cells can be positive for Ki67. For Ki67, the percentage of positive nuclei was obtained by manual count of at least 1000 cells in 10 high-power fields (400X) (Image Pro Plus ${ }^{\circledR}$ program). For ER and PR expression, scores were defined in relation to the percentage of positive cells (Score $0=$ negative, Score $1=$ positivity in $1-33 \%$ of cells, Score 2 = positivity in $34-66 \%$, Score 3 = positivity in $67-100 \%$ ). Other antibodies were used to exclude hemangiosarcoma (factor Von Willebrand), and to confirm the morphological diagnosis of TBNP and TWP (smooth muscle actin, desmin, GFAP, S100 and CD56).

Statistical analysis. Clinical information (sex and age of animals, size and location of lesions) was analysed using descriptive statistics.

Relative risk (Odds Ratio), with a confidence interval of 95\%, was used to evaluate breed predisposition (MedCalc statistical program easy to use statistical software ${ }^{7}$ ). To evaluate gender predisposition, the proportion of occurrence was calculated with a confidence interval of 95\%; statistically equal proportions were identified by overlapping intervals (package prop; test of the statistical software R) (R Development Core Team 2008).

ER and PR qualitative variables were compared between tumor grades and mitotic scores, using the non-parametric Wilcoxon test. The cellular proliferation index (KI67) was correlated with extent of PR immunostaining using Spearman's correlation (Statistical and Genetic Analysis System) (SAEG 1999).

\footnotetext{
${ }^{7}$ Available at <https://www.medcalc.org/calc/odds_Ratio.Php >
} 


\section{RESULTS}

\section{Clinical records information}

Eighty cases of canine STS with histopathological characteristics of PNST and/or PWT were selected. Thirtyfour $(42.5 \%)$ cases occurred in males and $46(57.5 \%)$ in females. The male/female ratio was 1:1.3. The age (known in 72 cases) ranged from 2 to 16 years, with an average of 10 years $( \pm 2.93)$ and mode of 12 years. The location of the tumors was mentioned in 74 cases, with more than half ( 40 cases, $54.0 \%$ ) occurring in the limbs (thoracic $24.3 \%$ and pelvic $29.7 \%$ ). Other anatomical regions were involved less frequently: trunk (20 cases, $27 \%$ ); face ( 6 cases, $8.1 \%$ ); digits ( 6 cases, $8.1 \%$ ); perineum ( 1 case, $1.35 \%$ ) and tail (1 case, $1.35 \%$ ). The size of the lesions (information obtained in 35 cases) ranged from 1.5 to $25 \mathrm{~cm}$ in diameter, with an average of $5.5 \mathrm{~cm}( \pm 4.9)$ and mode of $2.0 \mathrm{~cm}$.

Mongrel dog, Labrador Retriever, Maltese, Poodle, Boxer, Golden Retriever and Siberian Husky were the most frequently affected breeds. However, Siberian Husky (OR: 7.68, P = 0.0003 ) and the Maltese (OR: $2.60, \mathrm{P}=0.048$ ) were the most predisposed for the development of the disease; they showed a seven-fold and two-fold higher risk of disease development than the other breeds, respectively.

\section{Histopathology and Immunohistochemistry (IHC)}

The morphological diagnosis of PNST and PWT was confirmed, by positive immunostaining for neural and smooth muscle markers (GFAP, NSE, CD56, smooth muscle actin and desmin). All cases were negative for Von Willebrand factor.

Twenty-six cases $(32.5 \%)$ were histologically classified as grade I, $43(53.75 \%)$ as grade II and 11 cases $(13.75 \%)$ as grade III.

All 80 cases exhibited positive nuclear immunostaining for PR (Fig.1 and 2). Most of the tumors (53 cases, 66,25\%) showed positivity in at least $66 \%$ of the tumor cells (score 3 ).

All 80 cases were negative for ER.

There was a significant difference between the histological grades of the tumors in relation to PR expression. Grade III

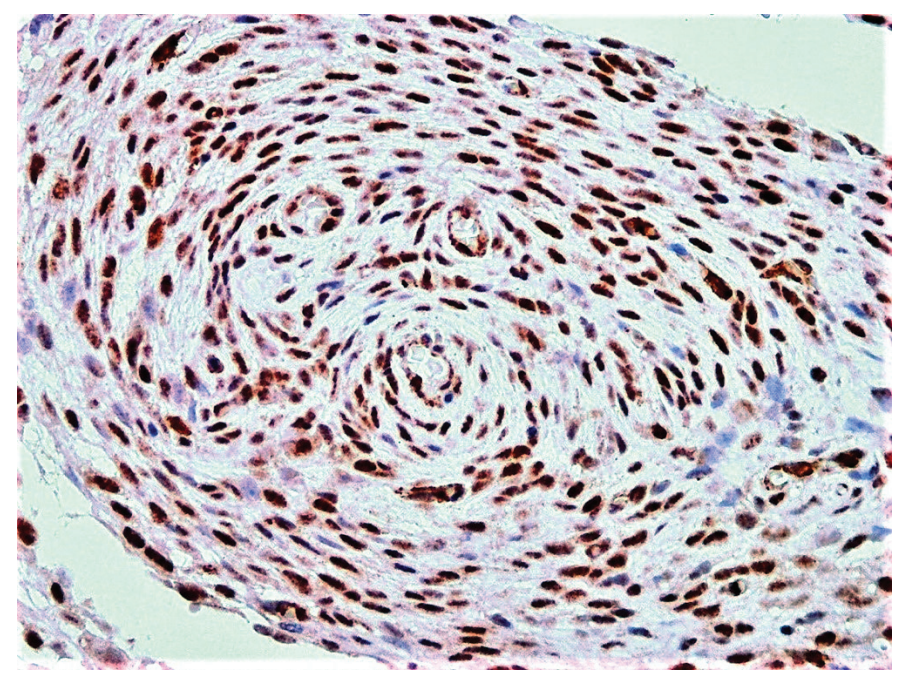

Fig.1. Canine Soft Tissue Sarcoma. Positive nuclear immunostaining for PR in cellular whorls. IHC counterstaining with Harris hematoxylin, obj.40x. tumors exhibited greater expression of this receptor than grade I tumors $(\mathrm{P}=0.015)$. The same difference occurred when grade I and II tumors were grouped and compared to grade III $(\mathrm{P}=0.028)$.

The PR expression varied significantly according to the mitotic index scores. Tumors with score 1 for mitotic activity (0-9 mitosis/10hpf) exhibited lower expression of this receptor than tumors with score 2 (10-19 mitosis/10hpf, $\mathrm{P}=0.011)$ and tumors with score 3 ( $\mathrm{P}=0.018$, >19 mitosis/10hpf).

Finally, there was a positive correlation between the cellular proliferation index (ki67) and PR expression ( $\mathrm{P}=0.05)$.

\section{DISCUSSION}

Receptors for steroid sex hormones regulate the transcription of genes involved in cellular proliferation and apoptosis, and act in cellular differentiation and as growth factors (Buffet et al. 2005, Fishbein et al. 2007, Sorbye et al. 2013).

The highest level of expression of PR in high-grade sarcomas (grade III) and those with high mitotic activity shows that this hormone may also be associated with tumor growth. Consistent with this, the Ki67 index correlated positively with the expression of PR as well. The positivity for PR across large extents of tissue in all cases points to the possible participation of progesterone in the development of these sarcomas.

Progesterone stimulates axon myelination during development and remyelination after injury (Schumacher et al. 2008). Schwann cells express PR and synthesize progesterone in response to neuronal signals (Patel et al. 2008). In vitro studies demonstrated that the Schwann cells derived from neurofibromas showed high proliferation in the presence of this steroid hormone (Overdiek et al. 2008). Here, all cases were positive for neural markers, and Schwann cells may be the main cellular component of these sarcomas. This explains the presence of PR in a high proportion of the cellular population, as well as its possible participation in cellular proliferation.

Similar to the IHC pattern found in the present study, neurofibromas in humans showed diffuse immunostaining for PR, with rare positivity for ER (McLaughlin \& Jacks 2003, Geller et al. 2008). Negativity for ER was also observed in

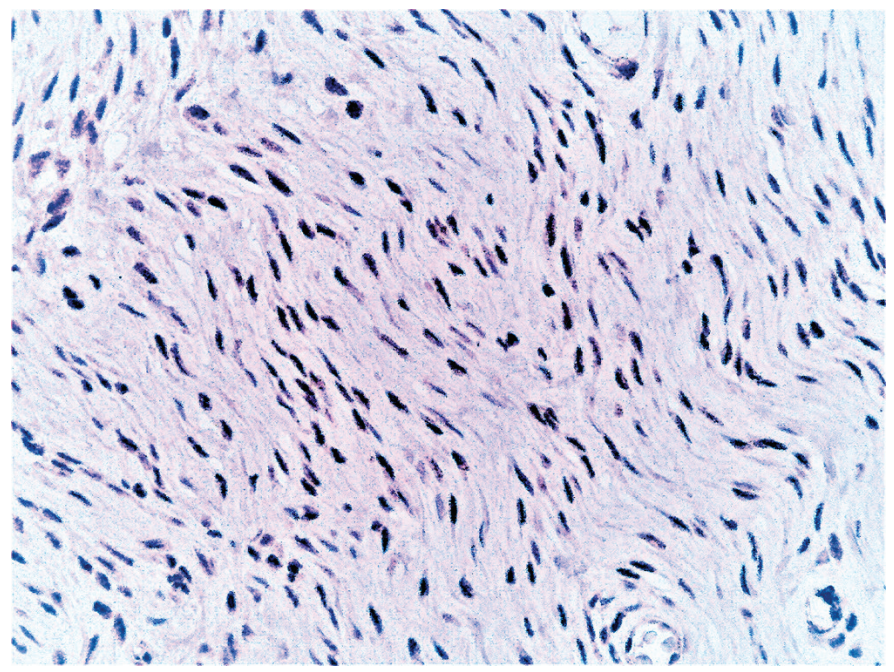

Fig.2. Canine Soft Tissue Sarcoma. Positive nuclear immunostaining for PR in undulating cellular bundles. IHC counterstaining with Harris hematoxylin, obj.40x. 
human vestibular schwannomas (Cafer et al., 2008, Jaiswal et al., 2009). On the other hand, STS of different histogenesis located at the extremities, positivity for ER was observed in $30 \%$ of 89 cases (Valkov et al., 2011). It is possible that there are differences in ER expression between species, individuals, histological type and even between the stages of neoplasm development. In the current study, the ER apparently did not participate in the growth and proliferation of these tumors.

PR may act as a possible predictive molecular marker of prognosis and therapeutic targets in canine spindle cell sarcomas, considering that in humans PR and ER expression in STS has been associated with variable survival times (Ioffe et al. 2009, Valkov et al. 2011, Li et al. 2013, Sorbye et al. 2013). Human patients with IHC profiles similar to that of this study (ER negative and PR positive) presented reduced survival (Valkov et al. 2011, Sorbye et al. 2013). When each sex was evaluated separately, PR expression in men was associated with poor prognosis and reduced survival (Valkov et al. 2011). Furthermore, the influence of steroid sex hormones on the growth of neurofibroma and vestibular schwannoma is well documented, with greater prevalence in women; there was an increase in the size, number of lesions or malignant transformation during periods of hormonal changes, particularly during puberty and pregnancy (Geller et al. 2008, Patel et al. 2008, Jaiswal et al. 2009, Brown et al. 2011). In dogs, future researches are needed to assess the relationship of STS RP expression, gender, reproductive status and prognostic factors (eg, recurrence, metastasis, diseasefree interval and survival time).

Also, the response to hormonal treatment (eg. selective ER or PR modulators, aromatase inhibitors) has also been described for several types of human STS (Ioffe et al. 2009, Byer et al. 2011, Meijer et al. 2011, Akashi et al. 2013, Li et al. 2013, Thanopoulou et al. 2014), which may prove to be useful in dogs with the evolution of the pathogenesis understanding.

Finally, in the present study, neoplasm size, location, and gender distribution did not differ from those described previously in the literature (Goldschmidt \& Shofer 1992, Ettinger et al. 2006, McSporran 2009, Bray 2016). A predisposition of the Siberian Husky for hemangiopericytomas was also noted, but the Maltese has not previously been reported as a predisposed breed (Goldschmidt \& Shofer 1992).

\section{CONCLUSION}

The presence of progesterone receptors (PR) in all cases reveals a promising area for future investigations, new therapeutic modalities and new molecular biomarkers of prognosis. In particular, selective PR modulators should be investigated as a possible approach in the treatment of canine soft tissue sarcomas (STS).

Acknowledgments.- To "Coordenação de Aperfeiçoamento de Pessoal de Nível Superior" (CAPES) for the PhD scholarship granted to Dr. Fabricia

Conflict of interest statement.- The authors have no competing interests.

\section{REFERENCES}

Akashi D., Todo Y., Shimada C., Okamoto K., Minobe S. \& Kato H. 2013. Successful use of dydrogesterone as maintenance therapy in recurrent endometrial stromal sarcoma: a case report. Jpn. J. Clin. Oncol. 43(11):1145-1149. <http://dx.doi.org/10.1093/jjco/hyt142><PMid:24058200>
Avallone G., Boracchi P., Stefanello D., Ferrari R., Rebughini A. \& Roccabianca P. 2014. Canine perivascular wall tumors: high prognostic impact of site, depth, and completeness of margins. Vet. Pathol. 51(4):713-721.<http:// dx.doi.org/10.1177/0300985813503565><PMid:24048324>

Bray J.P. 2016. Soft tissue sarcoma in the dog - part 1: a current review. J. Small Anim. Pract. 57(10):510-519. <http://dx.doi.org/10.1111/jsap.12556> <PMid:27624929>

Brown C.M., Ahmad Z.K., Ryan A.F. \& Doherty J.K. 2011. Estrogen receptor expression in sporadic vestibular schwannomas. Otol. Neurotol. 32(1):158-162. <http://dx.doi.org/10.1097/MA0.0b013e3181feb92a > <PMid:21099731>

Buffet N.C., Meduri G., Bouchard P. \& Spitz I.M. 2005. Selective progesterone receptor modulators and progesterone antagonists: mechanisms of action and clinical applications. Human Reprod. Update 11(3):293-307. <http:// dx.doi.org/10.1093/humupd/dmi002 > <PMid:15790602>

Byer S.J., Eckert J.M., Brossier N.M., Clodfelder-Miller B.J., Turk A.N., Carroll A.J., Kappes J.C., Zinn K.R., Prasain J.K. \& Carrol S.L. 2011. Tamoxifen inhibits malignant peripheral nerve sheath tumor growth in an estrogen receptor-independent manner. Neuro Oncol. 13(1):28-41.<http://dx.doi. org/10.1093/neuonc/noq146> <PMid:21075781>

Cafer S., Bayramoglu I., Uzum N., Yilmaz M., Memis L. \& Uygur K. 2008. Expression and clinical significance of Ki-67, oestrogen and progesterone receptors in acoustic neuroma. J. Laryngol. Otol.122(2):125-127.<http:// dx.doi.org/10.1017/S0022215107000229><PMid:17666143>

Dennis M.M., McSporran K.D., Bacon N.J., Schulman F.Y., Foster R.A. \& Powers B.E. 2011. Prognostic factors for cutaneous and subcutaneous soft tissue sarcomas in dogs. Vet. Pathol. 48(1):73-84. <http://dx.doi. org/10.1177/0300985810388820 > <PMid:21139143>

Ettinger S.N. 2003. Principles of treatment for soft-tissue sarcomas in the dog Clin. Techn. Small Anim. Pract. 18(2):118-122.<http://dx.doi.org/10.1053/ svms.2003.36628 > <PMid:12831074>

Ettinger S.N., Scase T.J., Oberthaler K.T., Craft D.M., Mcknight J.A., Leibman N.F., Charney S.C. \& Bergman P.J. 2006. Association of argyrophilic nucleolar organizing regions, Ki-67, and proliferating cell nuclear antigen scores with histologic grade and survival in dogs with soft tissue sarcomas: 60 cases (1996-2002). JAVMA 228(7):1053-1062. <http://dx.doi.org/10.2460/ javma.228.7.1053><PMid:16579784>

Fishbein L., Zhang X., Fisher L.B., Li H., Thompson M.C., Yachnis A., Rubenstein A., Muir D. \& Wallace M.R. 2007. In vitro studies of steroid hormones in neurofibromatosis 1 tumors and Schwann cells. Mol. Carcinogen. 46(7):512523. <http://dx.doi.org/10.1002/mc.20236><PMid:17393410>

Geller M., Mezitis S.G.E., Nunes F.P., Ribeiro M.G., Araújo A.P.Q.C., Bronstein M.D. Batista R.S., Gomes A.P., Oliveira L. \& Cunha K.S.G. 2008. Progesterone and estrogen receptors in neurofibromas of patients with NF1. Clin. Med. Pathol. 1:93-97. <http://dx.doi.org/10.4137/cpath.s1002> <PMid:21876657>

Goldschmidt M.H. \& Shofer F.S. 1992. Skin Tumors of the Dog and Cat. Pergamon Press, Great Britain. 316p.

Ioffe Y.J., Li A.J., Walsh C.S., Karlan B.Y., Leuchter R., Forscher C. \& Cass I. 2009. Hormone receptor expression in uterine sarcomas: prognostic and therapeutic roles. Gynecol. Oncol. 115(3):466-471. <http://dx.doi. org/10.1016/j.ygyno.2009.08.014><PMid:19767065>

Jaiswal S., Agrawal V., Jaiswal A.K., Pandey R. \& Mahapatra A.K. 2009. Expression of estrogen and progesterone receptors in vestibular schwannomas and their clinical significance. J. Negat. Results Biomed. 8(1):9. <http://dx.doi. org/10.1186/1477-5751-8-9><PMid:19889208>

Li L., Schuster I.P., Jacob R., Hupart K.H. \& Gotlieb V. 2013. Potential benefit of hormonal therapy for non-uterine soft tissue sarcoma (STS) - a case report and literature review. Springerplus 2(1):536. <http://dx.doi. org/10.1186/2193-1801-2-536><PMid:24255838>

McLaughlin M.E. \& Jacks T. 2003. Progesterone receptor expression in neurofibromas. Cancer Res. 63(4):752-755. <PMid:12591720> 
McSporran K.D. 2009. Histologic grade predicts recurrence for marginally excised canine subcutaneous soft tissue sarcomas. Vet. Pathol. 46(5):928933. <http://dx.doi.org/10.1354/vp.08-VP-0277-M-FL><PMid:19429989>

Meijer D., Gelderblom H., Karperien M., Cleton-Jansen A.M., Hogendoom P.C.W. \& Bovee J.V.M.G. 2011. Expression of aromatase and estrogen receptor alpha in chondrosarcoma, but no benefical effect of inhibiting estrogen signaling both in vitro and in vivo. Clin. Sarcoma Res. 1(1):1-9. <http:// dx.doi.org/10.1186/2045-3329-1-5><PMid:22613849>

Millanta F., Calandrella M., Bari G., Niccolini M., Vannozzi I. \& Poli A. 2005. Comparison of steroid receptor expression in normal, dysplastic and neoplastic canine and feline mammary tissues. Res. Vet. Sci. 79(3):225232. <http://dx.doi.org/10.1016/j.rvsc.2005.02.002><PMid:16054892>

Millanta F., Calandrella M., Vannozzi I. \& Poli A. 2006. Steroid hormone receptors in normal, dysplastic and neoplastic feline mammary tissues and their prognostic significance. Vet. Rec. 158(24):821-824. <http:// dx.doi.org/10.1136/vr.158.24.821><PMid:16782855>

Overdiek A., Winner U., Mayatepek E. \& Rosenbaum T. 2008. Schwann cells from human neurofibromas show increased proliferation rates under the influence of progesterone. Pediatr. Res. 64(1):40-43. <http://dx.doi. org/10.1203/PDR.0b013e31817445b8> <PMid:18360307>

Patel A.K., Alexander T.H., Andalibi A., Ryan A.F. \& Doherty J.K. 2008. Vestibular schwannoma polymerase chain reaction expression of estrogen and progesterone receptors. Laryngoscope 118(8):1458-1463.<http://dx.doi. org/10.1097/MLG.0b013e318177e20b><PMid:18670322>
R Development Core Team 2008. R: A language and Environment for Statistical Computing. R Foundation for Statistical Computing, Vienna. Available at <http://www.R-project.org> Accessed on May 12, 2020.

SAEG 1999. Sistema de Análise Estatística e Genética (SAEG), Central de processamento de dados, Universidade Federal de Viçosa (UFV), Viçosa, MG.

Schumacher M., Ware R.S. \& Nicola A. F. 2008. Progesterone and progestins: neuroprotection and myelin repair. Curr. Opin. Pharmacol. 8(6):740-746. <http://dx.doi.org/10.1016/j.coph.2008.10.002> <PMid:18929681>

Sorbye S.W., Kilvaer T.K., Valkov A., Donnem T., Smeland E., Al-Shibli K., Bremnes R.M. \& Busund L.T. 2013. Prognostic impact of Skp2, ER and PFR in male and female patients with soft tissue sarcomas. BMC Clin. Pathol. 13(9):113. <http://dx.doi.org/10.1186/1472-6890-13-9><PMid:23497154>

Thanopoulou E., Thway K., Khabra K. \& Judson I. 2014. Treatment of hormone positive uterine leiomyosarcoma with aromatase inhibitors. Clin. Sarcoma Res. 4(5):1-8. <http://dx.doi.org/10.1186/2045-3329-4-5><PMid:25018868>

Vail D.M. \& Macewen E.G. 2000. Spontaeously occurring tumors of companion animals as models for human cancer. Cancer Investig. 18(8):781-792. <http://dx.doi.org/10.3109/07357900009012210> <PMid:11107448>

Valkov A., Sobye S., Kilvaer T.K., Donnem T., Smeland E., Bremnes R.M. \& Busund L.T. 2011. Estrogen receptor and progesterone receptor are prognostic factors in soft tissue sarcomas. Int. J. Oncol. 38(4):1031-1040. <http:// dx.doi.org/10.3892/ijo.2011.920><PMid:21271213> 